\title{
Ideophones (Mimetics, Expressives)
}

\author{
Kimi Akita ${ }^{1}$ \\ Graduate School of Humanities \\ Nagoya University
}

\author{
Mark Dingemanse \\ Centre for Language Studies \\ Radboud University
}

\begin{abstract}
Ideophones, also termed "mimetics" or "expressives," are marked words that depict sensory imagery. They are found in many of the world's languages, and sizable lexical classes of ideophones are particularly well-documented in languages of Asia, Africa, and the Americas. Ideophones are not limited to onomatopoeia like meow and smack, but cover a wide range of sensory domains, such as manner of motion (e.g., plisti plasta 'splish-splash' in Basque), texture (e.g., tsaklii 'rough' in Ewe), and psychological states (e.g., wakuwaku 'excited' in Japanese). Across languages, ideophones stand out as marked words due to special phonotactics, expressive morphology including certain types of reduplication, and relative syntactic independence, in addition to production features like prosodic foregrounding and common co-occurrence with iconic gestures.

Three intertwined issues have been repeatedly debated in the century-long literature on ideophones. (a) Definition: Isolated descriptive traditions and cross-linguistic variation have sometimes obscured a typologically unified view of ideophones, but recent advances show the promise of a prototype definition of ideophones as conventionalised depictions in speech, with room for language-specific nuances. (b) Integration: The variable integration of ideophones across linguistic levels reveals an interaction between expressiveness and grammatical integration, and has important implications for how to conceive of dependencies between linguistic systems. (c) Iconicity: Ideophones form a natural laboratory for the study of iconic form-meaning associations in natural languages, and converging evidence from corpus and experimental studies suggests important developmental, evolutionary, and communicative advantages of ideophones.
\end{abstract}

${ }^{1}$ The authors contributed equally to this article Correspondence: akita.kimi@nagoya-u.jp,m.dingemanse@let.ru.nl

\section{Definition}

Ideophones are marked words that evoke vivid sensory scenes in imitative fashion. They are abundant in language families across the globe, such as Bantu, Austroasiatic, Dravidian, and Quechuan, as well as Basque, Japanese, and Korean. Some examples are cited in Table 1.

Although sound imitatives like boom and splash have been known in Western linguistics from early on, it was only when linguists began to describe a wider range of languages that a larger class of imitative words came to light (cf. Vidal, 1852 on Yorùbá; Aston, 1894 on Japanese; Urtel, 1919 on Basque). As the term ONOMATOPOEIA by that time had acquired derogatory connotations (Moore, 2015) and was mostly understood to be limited to sound imitatives, many scholars invented new terms for this larger class, from "specific adverbs" to Lautbilder ('sound images') and from "echoisms" to mots expressifs ('expressive words'). The new term that caught on most widely was IDEOPHONES, introduced by Doke (1935). Today, this is the term used for lexical classes of imitative words in languages across the globe, from Basque to Zulu and from Korean to Quechua. Two other terms - mimetics in Japanese linguistics and expressives in South and Southeast Asian linguistics - are regarded as largely equivalent, and we use 'ideophones' as a cover term to include these variants. 


\begin{tabular}{|c|c|c|}
\hline Language & Affiliation & Examples of ideophones \\
\hline $\begin{array}{l}\text { Ngbaka } \\
\text { Gbaya }\end{array}$ & $\begin{array}{l}\text { Ubangian, Niger- } \\
\text { Congo }\end{array}$ & 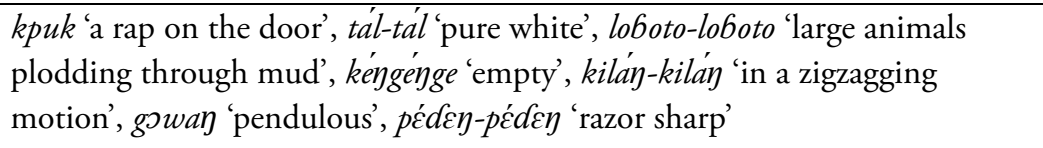 \\
\hline Semai & $\begin{array}{l}\text { Mon-Khmer, } \\
\text { Austroasiatic }\end{array}$ & $\begin{array}{l}d h d \eta \mathrm{s} h \text { 'appearance of nodding constantly', bye: } k \text { 'white', praduk pradzk } \\
\text { 'noises of scattered small drops of rain', blb?al 'painful embarrassment', } \\
\text { rnrubs:n 'the appearance of teeth attacked by decay' }\end{array}$ \\
\hline Somali & $\begin{array}{l}\text { East Cushitic, } \\
\text { Afro-Asiatic }\end{array}$ & $\begin{array}{l}\text { shalalab 'sound of rain dripping', juluq 'to gulp down (something solid) } \\
\text { without chewing', jac 'to crackle', halalac 'to give off a sparkling light', dhag } \\
\text { 'to puncture making a small hole' }\end{array}$ \\
\hline Korean & Probable isolate & 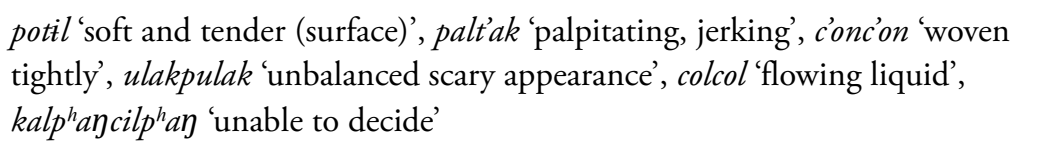 \\
\hline $\begin{array}{l}\text { Pastaza } \\
\text { Quechua }\end{array}$ & $\begin{array}{l}\text { Quechua IIB, } \\
\text { Quechuan }\end{array}$ & $\begin{array}{l}\text { dzing 'a sudden awareness or intuition, especially one that causes fright', sa } \\
\text { 'expanded or random movement from or within a locus', tsung 'to absorb, } \\
\text { cover, or drench with a liquid substance', palay 'to fall rapidly and/or } \\
\text { peltingly, as a collectivity of entities' }\end{array}$ \\
\hline $\begin{array}{l}\text { Upper } \\
\text { Necaxa } \\
\text { Totonac }\end{array}$ & Totonac-Tepehua & 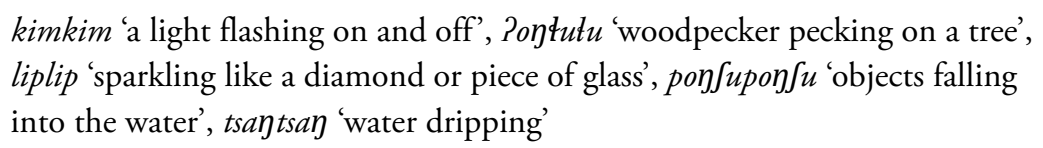 \\
\hline Siwu & $\begin{array}{l}\text { Kwa, Niger- } \\
\text { Congo }\end{array}$ & 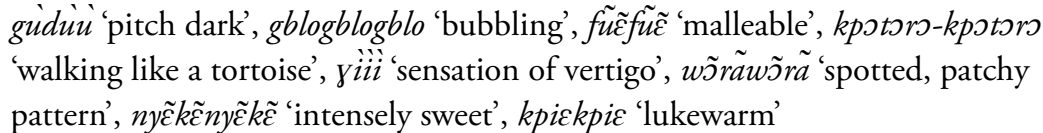 \\
\hline
\end{tabular}

Table 1. Ideophones across languages (adapted from Dingemanse, 2012, p. 661)

Doke was one of the first to insist that, at least in Bantu languages, ideophones formed a lexical class on a par with more widely used categories like noun and verb. He defined "ideophone" as follows:

(1) A vivid representation of an idea in sound. A word, often onomatopoeic, which describes a predicate, qualificative or adverb in respect to manner, colour, sound, smell, action, state or intensity. ... It must be pointed out that generally the special rules of length, tone and stress, applicable in ordinary grammatical forms, differ considerably in the case of ideophones. (Doke, 1935, pp. 118-119)

Although Doke's definition was intended for use in grammars of Bantu languages, many of its elements have been found to be relevant across languages, and make their appearance in later cross-linguistic characterisations (Samarin, 1965; Diffloth, 1972; Childs, 1994), including the definition of ideophones we will adopt here: "marked words that depict sensory imagery" (Dingemanse, 2012).

\subsection{Markedness}

One of the most striking properties of ideophones is their formal markedness at different levels of linguistic structure, chief among them phonology (Diffloth, 1979; Childs, 1988; Klamer, 2002; Kruspe, 2004, among others). Onomatopoeia have long been known as words whose iconicity allows them to violate regular phonotactic rules, as in the marked onset of English vroom 'sound of an engine' and coda of buzz 'sound of bees flying' (for a discussion of iconicity in ideophones, 
see Section 3). Likewise, many ideophones in Hausa have consonant-final structure (e.g., tsit 'in a complete silence, hush' tsúlúm 'sound of a small object falling in water', kàzàr-kázár 'in an energetic manner') whereas most regular Hausa words end in a vowel (Newman, 2001, p. 252). The phoneme /p/ in Japanese is prevalent in ideophones (e.g., petapeta 'slapping') but absent in prosaic native words, another example of how ideophones can deviate from regular phonology (Hamano, 1998).

Other aspects of the formal composition of ideophones also show their markedness. Many ideophones show feature harmony for vowels, tone or nasalisation (Kwon, 2018). Relatedly, ideophones in many languages show nonconcatenative or templatic morphology, with groups of ideophones forming small clusters of similar forms with similar meanings (McCarthy, 1983; McFarland, 2010; Tufvesson, 2011). Ideophones are also marked in the degree to which they are susceptible to playful processes of word formation like expressive lengthening and reduplicative morphology (Zwicky \& Pullum, 1987). Thus, reduplication is common in ideophones, where it tends to express iterative aspect (e.g., curukcuruk-nu 'many sharp pricks' in Tamil, Dravidian; Gasser, Sethuraman, \& Hockema, 2010) or intensification (e.g., Japanese kutakuta 'exhausted'). The syntactic distribution of ideophones tends to be marked as well: ideophones predominantly appear in affirmative-declarative sentences, even resisting negation in some languages (Diffloth, 1972 on Semai, Austroasiatic; Childs, 1994 on Kisi, Niger-Congo). However, this type of restriction appears to be weakened when ideophones are grammatically integrated with prosaic language (Newman, 1968 on Hausa, Afro-Asiatic; Dhoorre \& Tosco, 1998 on Somali, AfroAsiatic; see Section 2).

\subsection{Depiction}

The vivid meanings of ideophones have been described in terms of a separate representational mode of meaning: an "expressive" or "affecto-imagistic" dimension (Diffloth, 1972; Kita, 1997). In this semantic dimension, "language has direct contact with sensory, motor, and affective information" (Kita, 1997, p. 380). The special mode of representation of ideophones can be further explicated by drawing on the semiotic distinction between "depiction" and "description" (Clark \& Gerrig, 1990; Güldemann, 2008; Ferrara \& Hodge, 2018). To say that ideophones are depictions is to say that like images or manual gestures, "they show rather than tell, they perform rather than merely inform" (Dingemanse \& Akita, 2017, p. 505). So bilbàlà in (2) invites the hearer to simulate the depicted experience and "hear" the sound of the log rolling down noisily as if s/he were in the reported world (see also Nuckolls, 1996).

\section{(2) Ò dé lá à dàngmáá lóó, bilbàlà \\ 3.SG take FOC DEF log throw.down IDPH \\ 'He threw down the log, bilbàlä' (Dagaare, Niger-Congo; Bodomo 2006, p. 205) \\ (emphasis throughout this article is ours)}

This semiotic characteristic makes ideophones distinct from interjections, such as ah and ouch, which may also have marked forms and index sensory experiences but are typically responsive rather than depictive. Depictions - from pictures to gestures, and from quotations to ideophones - are characterised by iconic form-meaning mappings and gradient use of material, where changes in form analogously correspond to changes in meaning. Descriptions on the other hand are characterised by arbitrary form-meaning mappings and discrete building blocks, as in the phonemes or letters that form prosaic words. Seeing ideophones as depictions helps explain their iconicity and gradient formal features. In this semiotic model, ideophones are understood as 
lexicalised depictions of sensory imagery in speech.

While marked forms and depictive features are typical of ideophones as a lexical class, they are best seen as prototypical features rather than as necessary and sufficient properties (Childs, 1994; Akita, 2009; Dingemanse, 2012). For example, many onomatopoeic ideophones in English, such as crash and plop, are morphophonologically indistinguishable from prosaic words. Moreover, reduplication is a productive morphological operation in both ideophonic and prosaic lexicons of some languages (Mattes, 2007, 2018). Furthermore, some words may be considered more ideophonic than others, as illustrated by the Japanese ideophone chokichoki 'snipping repeatedly' and its related but more prosaic-like form chokkiri 'exact' (Akita, 2009). Because of the fuzzy and heterogeneous nature of the ideophone category, it has been common to view it as a prototype category, making it similar to major lexical categories such as the verb and noun (Dryer, 1997; Croft, 2001; Haspelmath, 2007). The next section takes a closer look at the way ideophones and prosaic words coexist in the linguistic system, another longstanding issue in the literature.

\section{Integration}

\subsection{Phonological and morphological integration}

The markedness of ideophones as a class is often seen as one of their most noteworthy features. This sometimes leads to the misconception that ideophones are completely unlike other words, insulated from the prosaic linguistic system (as pointed out by Newman, 2001). In reality, even if ideophones are marked in several ways, they are still constructed mostly out of the same phonemic building blocks as prosaic words. This is because, in Tucker Childs' memorable formulation, they have to "reconcile the twin dicta of 'Be different' and 'Be recognizably language"' (Childs, 2014). This dual nature has implications for theories of phonological and lexical structure.

A first sign of the linguistic status of ideophones is that their phonological buildup, while marked in several ways, usually bears a transparent relation to the broader phonological system. For instance, in the (relatively rare) cases where they feature speech sounds that are marginal in prosaic words, these sounds tend to fill gaps in the system. Japanese $/ \mathrm{p} /$, found in the ideophonic part of the native lexicon, fills what would otherwise be a gap in a system that has regular voicing alternations in the alveolar and velar obstruent series (Itô \& Mester, 1995). Likewise, Iroquioan phonology lacks a labial stop series, but ideophonic words fill this gap, featuring $/ \mathrm{p} /$ and $/ \mathrm{b} /$ (Mithun, 1982). In other cases, ideophones may show phoneme distributions that are more restricted than in other words. Hindi has 21 vowel phonemes, but only three of them (/a, i, u/) occur in prototypical ideophones (Kellersmann, 2017). In Korean, ideophones feature steminternal vowel harmony, which does not occur in prosaic words (Kwon, 2018).

To capture these facts about the phonology of ideophones, it is not sufficient to stress their deviance. Instead, the phonology of ideophones is best seen as a transformation of the phonology of prosaic words. In a detailed study of Pastaza Quichua by Nuckolls and colleagues, the phonology of ideophones is described as a "stretched" and "contracted" relative to other words (Nuckolls, Nielsen, Stanley, \& Hopper, 2016). According to one influential proposal, these transformations are sufficiently systematic to speak of an expressive phonology distinct but related from prosaic phonology: a system "where the structural elements necessary for prosaic language are deliberately re-arranged and exploited for their iconic properties, and used for aesthetic communication" (Diffloth, 1979, p. 58).

In morphology likewise, ideophones waver between markedness and integration depending on how and where we look. They do not partake in many regular morphological processes, which is one reason for their definition as strings directly mappings phonology to semantics "without 
passing through the morphological component of the grammar" (Johnson, 1976, p. 241). Instead they are particularly susceptible to playful word formation processes like lengthening and reduplication, dubbed "expressive morphology" in analogy to Diffloth's expressive phonology (Zwicky \& Pullum, 1987). Here, too, we may explain the pattern by reference to origin of ideophones as iconic forms, using speech material in a more fluid and gradient way than prosaic words.

This does not mean that ideophones are entirely insulated from more prosaic parts of the vocabulary. Indeed reduplication can function as a bridge between the two. In Siwu, some reduplicated ideophones are related to verb roots (e.g., $b \varepsilon \mathrm{V}$ 'be wide' $\leftrightarrow b \varepsilon b \varepsilon \varepsilon b \varepsilon$ IDPH 'wide', mini $\mathrm{V}$ 'encircle' $\leftrightarrow$ minimini IDPH 'circular'). Japanese has quite a few verbs with putative ideophonic origin (Hamano, 1998):

(3) Deideophonised verbs in Japanese:

a. zawa-tsuk $(-u)$ 'murmur' (< zawazawa 'a crowd murmuring')

b. koro-gar (-u) 'roll' (< korokoro 'a light object rolling continuously')

c. hika-r(-u) 'shine' (<pikapika 'shining brightly')

d. sawa-g(-u) 'make noise' (< zawazawa 'a crowd murmuring')

None of these verbs retain the reduplicated morphology of the input ideophones. Native speakers of Japanese are unlikely to recognise the ideophonic origin of the verbs in (3c-d), whose initial consonants have been changed to conform to prosaic phonology. [p] and voiced obstruents cannot stand in the initial position of prosaic native words in Japanese except for limited registers (Hamano, 1998). Such "deideophonisation," in which ideophones are integrated into the prosaic lexicon at the expense of their prototypical ideophonic properties, is a common phenomenon across ideophone-rich languages (Tamori \& Schourup, 1999; Childs, 2001).

Deideophonisation is also common at the semantic level. Some languages have (quasi-) ideophonic items whose meanings are as abstract as intensifiers and are used with a broad range of predicates. For example, the Ewe ideophones gbagbä 'on the point of overflowing (of a pot)' and (k)pey (k)pey 'blows resounding' appear to be the sources of the reduplicated adverbials gbagbagba 'very much, with emphasis' and pémpem 'very, completely' (Bartens, 2000, p. 29; Ameka, 2001).

\subsection{Morphosyntactic integration}

In many languages, ideophones tend to be found at the edge of an utterance or even as independent utterances, as in (4) as well as (2) above, which made Kunene (1965) describe them as syntactically "aloof".

(4) Wirr inggirr.

IDPH pulled.out

'Wirr! [He] pulled [it] out.' (Yir-Yoront, Paman; Alpher, 2001, p. 20)

Although some degree of syntactic independence is the rule for most ideophones in most languages, the syntactic behaviour of ideophones is more varied than examples like the above suggest. Many languages feature multiple morphosyntactic constructions for ideophones, and one and the same ideophone may occur in different constructions.

One grammatical context for ideophones found in many languages is a quotative construction (Güldemann, 2008; Akita \& Usuki, 2016), as in (5). This kind of construction has the potential to bridge the semiotic gap between ideophones and more prosaic forms of speech. 
a. in-komo i-thi $m h u-u-u$ xa i-khala-yo

9-cattle 9-say IDPH when 9-bellow-REL

'a cow says moo when it bellows' (Xhosa, Niger-Congo; Güldemann, 2008, p. 276)

b. It goes creak, creak (Rhodes, 1994, p. 281)

c. Kaeru ga pyokopyoko to hane-te i-ta.

frog NOM IDPH QUOT jump-GER be-PST

'A frog was jumping around quickly.' (Japanese, Akita \& Usuki, 2016, p. 246)

In many languages, light or dummy verb constructions further incorporate ideophones into the sentence structure, as in (6) (Langdon, 1994; Schaefer \& Egbokhare, 2002; Franco, 2017). One may also analyse (5a) as a light verb construction.
a. mia2 laaw2 hêt1
tòk1-pòk1
juul
wife 3SG.FA do
IDPH
CONT
'His wife is being squat, comical' (Lao, Kra-Dai; Enfield, 2007, p. 301)

$\begin{array}{lllll}\text { b. Biak } & \text { irrist egin eta biak lurrera doaz } \\ \text { 2.abs.pl } & \text { IDPH make and } & \text { 2.abs.plground.all aux }\end{array}$
'Both slid and both fell down irrist' (Basque; Ibarretxe-Antuñano, 2006, p. 20)

The specific set of constructions available to ideophones - and the relative degree of morphosyntactic integration associated with it - differs from language to language, and as a result, the grammatical-categorial status of ideophones has been actively debated for half a century, often in relation to the definitional issues described in Section 1 (Newman, 1968; Samarin, 1971; Bartens, 2000). Although many ideophones in many languages are adverbial (Watson, 2001), Somali ideophones are nominal (Afro-Asiatic; Dhoorre \& Tosco, 1998), and Cantonese has many adjectival ideophones (Sino-Tibetan; Bodomo, 2006). It remains to be elucidated what determines the morphosyntactic potential of ideophones in each language and how this relates to broader issues in syntactic typology.

Compared to other words, ideophones typically exhibit a high degree of expressiveness as measured in terms of intonational foregrounding, special types of phonation, and expressive morphology (Childs, 1994; Nuckolls, 1996). However, as the examples above show, they may vary considerably in terms of grammatical integration. Recent research suggests an inverse relation between expressiveness and morphosyntactic integration: higher expressiveness goes together with lower integration and vice versa (Dingemanse \& Akita, 2017). The dynamic is illustrated in (7), taken from the NHK East Japan Great Earthquake archives, a multimodal corpus of spoken Japanese. The first two ideophone tokens - both gitchiri 'tightly' - function as adverbs and are pronounced with intonational foregrounding, i.e. a pitch that is distinctly higher than the surrounding material (marked $\uparrow \ldots \uparrow$ ). Both instances are accompanied by a hand gesture (marked $\left[{ }_{\mathrm{G}} \ldots\right]$ ) that demonstrates the holding action. On the other hand, such paralinguistic and nonverbal features are not found with two ideophonic items that are more deeply embedded in the morphosyntactic structure of the utterance: the predicative ideophone bikkuri-shi be surprised' and the event-general, deideophonised adverb yukkuri 'slowly'.

(7) Moo [G $\uparrow$ gitchiri $\uparrow$ ] tsukamat-te i-mashi-ta. Tonikaku te ga itaku naru gurai [G $\uparrow$ gitchiri $\uparrow$ ] tsukamat-te ... aruk-u teido de, yukkuri oi-kake-te it-te. Soshite "Suimasen" te it-tara, mukoo no hito ga bikkuri-shi-chat-te...

'[I] was holding tightly to [it]. [I] was holding tightly enough to have a pain in [my] hands ... [I] walked and chased [the person I found over there] on slowly. And when [I] said, 
"Excuse me," the person was surprised ...'

(http://www9.nhk.or.jp/archives/311shogen/detail/\#dasID=D0007010111_00000)

The inverse relation between expressiveness and morphosyntactic integration turns out to be a feature of ideophones across a wide range of languages. Besides the ten languages identified as showing an interaction like this (Dingemanse \& Akita, 2017 - the main source of Table 2 below), further work has replicated the finding in Basque (Ibarretxe-Antuñano, 2017), Korean (Park, 2018), and Wao Terero (Fawcett, 2018). There is also a possible attestation of a boundary case predicted by the theory: in three related Luhya languages (Bantu, Niger-Congo), ideophones are consistently low in expressiveness and high in morphosyntactic integration (Bowler \& Gluckman, 2017). Table 2 lists the languages for which there is published evidence on the relation between expressiveness and morphosyntactic integration of ideophones.

\begin{tabular}{lll}
\hline Language & Phylum & Macro-area \\
\hline Bambara & Mande & Africa \\
Shona & Bantu & Africa \\
Siwu & Kwa & Africa \\
Somali & Cushitic & Africa \\
Basque & Vasconic & Eurasia \\
Japanese & Japonic & Eurasia \\
Semelai & Aslian & Eurasia \\
Jaminjung & Mirndi & Australia \\
Yucatec Maya & Mayan & North America \\
Pastaza Quichua & Quechuan & South America \\
Awetí & Tupian & South America \\
\hline
\end{tabular}

Table 2. Languages that exhibit the expressiveness-integration interaction

Expressiveness in ideophones helps signal their depictive mode of signification: it sets them apart as words that show rather than tell. This status aparte is reinforced by their grammatical independence, which explains the inverse relation between expressiveness and grammatical integration found in many languages. Additional evidence for this inverse relation comes from gesture. Across languages, iconic gestures are most likely to co-occur with ideophones when they are at their most depictive, as marked by high levels of expressiveness and low levels of grammatical integration (Kunene, 1965 for Sesotho; Reiter, 2012 for Awetí; Dingemanse \& Akita, 2017 for Japanese and cross-linguistic evidence). This strongly suggests that a full understanding of ideophones as depictions calls for a multimodal examination that takes into account both linguistic and extra-linguistic features (see Nuckolls et al., 2016-present for a videoaided illustration of Pastaza Quichua ideophones).

\section{Iconicity in Ideophones}

One of the more commonly mentioned properties of ideophones is iconicity: the resemblance between aspects of forms and meanings. Iconicity in ideophones takes on several forms, is used for a range of functions, and has consequences for linguistic theory - the three main topics taken up in this section. A caveat: ideophones are sometimes simply defined as iconic words (Johnson, 1976; Tedlock, 1999), but this is an oversimplification for two reasons: (i) the form-meaning associations found in ideophones range from those that are easily detectable for non-native 
speakers (and potentially universal) to those that are more dependent on properties of the local linguistic system (and potentially lineage-specific); and (ii) as conventionalised items that have to be learned and show varying degrees of linguistic integration, ideophones will always show some arbitrary properties as well.

\subsection{Forms of iconicity}

Lexical iconicity is a perceived resemblance between aspects of form and meaning in lexical items. In spoken words, this form of iconicity is sometimes called sound-symbolism. Ideophones offer one of the best places to observe the possibility space for iconic associations between sound and sense. Formal aspects of speech like acoustic properties, articulatory gestures, prosody, and higherlevel features like syllable structure and reduplication may be iconically associated with a wide range of semantic features like sound, size, movement, intensity, texture, duration, aspect, and valence (Westermann, 1927; Diffloth, 1972; Nuckolls, 1999; Mihas, 2012).

Take Japanese hisohiso 'whispering secretively' (Kakehi, Tamori, \& Schourup, 1996, p. 529). The fricated, unvoiced consonants help to depict an acoustic image of whispering (a form of IMAGIC iconicity). The reduplicated syllables provide a perceptual analogy to the durative aspect of the depicted event (a form of DIAGRAMMATIC iconicity). However, not all aspects of the ideophone can be given a straightforward iconic interpretation: the syllable structure appears to be determined more by Japanese phonotactic rules than by iconic considerations, and it is not clear that the vowels make specific contributions. ${ }^{1}$ Likewise, not all aspects of the meaning ascribed to an ideophone necessarily have counterparts in its form: for instance, the 'secretive' connotation of hisohiso is likely a pragmatically enriched rather than an iconically encoded meaning. This combination of iconicity, arbitrariness, and pragmatically enriched meanings is typical of ideophones across languages.

How do we know our iconic interpretations of hisohiso are on firm ground? They barely rise above the level of intuitions, making them susceptible to cherry-picking and confirmation bias. Intuitive accounts of iconic mappings are still surprisingly common in work on ideophones, and they represent the soft underbelly of the field. The way forward is to treat them as placeholders for independent empirical evidence. The gold standard is experimental data: to the extent that an ideophone resembles aspects of its meaning, it should be easier to learn or to guess. When given hisohiso and two possible meanings, 'whispering' and 'shouting', naïve speakers of Dutch chose the right meaning $97 \%$ of the time (Lockwood, Hagoort, \& Dingemanse, 2016).

Cross-linguistic data is a second source of evidence for iconic mappings. The association between unvoiced fricatives and the sound of whispering is found not just in Japanese hisohiso but also in equivalents like Korean s'oktaksoktak and Mandarin Chinese xisuo (Akita, 2013a, p. 26). When a form-meaning association is found in multiple unrelated languages, it is more likely to be a bona fide case of iconicity. ${ }^{2}$ Experimental and cross-linguistic evidence like this makes it possible to turn just-so stories about iconicity into empirically grounded explanations.

While hisohiso seems to be primarily about sound, ideophones can provide crossmodal associations to all sorts of sensory scenes, as in Siwu gbadara-gbadara 'a drunkard's wobbling gait', Korean c'ukilc'ukil 'wrinkled, e.g. as an un-ironed shirt', or Japanese fuwafuwa 'fluffy'. In languages

\footnotetext{
${ }^{1}$ Unlike some other ideophones, this form does not occur in minimal pairs that allow us to draw conclusions about the absolute or relative iconic contributions of vowels or consonant voicing (Hamano, 1998).

${ }^{2}$ Note this is phrased in terms of probability, not necessity. Since both form and meaning have many dimensions, the possibility space for iconic mappings is large (though not without limit), and languages may use iconic affordances in different ways. Lexical iconicity is probabilistic, not deterministic (Dingemanse, 2018).
} 
with large ideophone inventories, sound-imitative ideophones appear to form a minority (Samarin, 1965), perhaps simply because there are only so many events that make sound, and many more that offer other affordances for iconic associations.

The cumulative progression from concrete imagic to more abstract diagrammatic associations can be traced in the ontogeny and typology of spoken languages. In ontogeny, onomatopoeia are among the earliest learned words (Laing, 2014). Although acquisition studies of languages with large ideophone systems are still relatively rare, evidence from Japanese suggests that ideophones imitative of sound ('phonomimes') are learned earlier than those imitative of other sensory scenes (Herlofsky, 1998), and that they show relatively more morphosyntactic freedom than other ideophones (Hamano, 1988; Akita, 2009). This has led Akita to posit a "Lexical Iconicity Hierarchy" according to which phonomimes are ranked before phenomimes and psychomimes (Akita, 2009, 2013b). In typology, a similar cumulative progression is observed in the composition and distribution of ideophone systems: ideophones imitative of sound are universally attested, closely followed by ideophones imitative of motion and visual patterns, while ideophones that show more abstract iconic associations tend to be found in languages with larger ideophone inventories. This can be formulated as an implicational hierarchy: there is no language without ideophones imitative of sound; if a language has ideophones for motion, it also has ideophones for sound; and so on (Dingemanse, 2012).

(8) Lexical Iconicity Hierarchy (Akita 2009)

Phonomimes $>$ Phenomimes $>$ Psychomimes

Implicational hierarchy of ideophone systems (Dingemanse 2012)

Sound $>$ Movement $>$ Visual patterns $>$ Other sensory perceptions $>$ Inner feelings and sensations

\subsection{Functions of iconicity in ideophones}

When using an ideophone, "the speaker conjures up before the eyes of his listeners events which are not actually happening, or states which are not existing, at the time of speaking. It is for this reason that ideophones are so often accompanied by gestures of mimicry" (Kunene, 1965, p. 21). One place where such "conjuring up" is useful is in storytelling, and indeed stories have long been identified as a key locus of ideophone use (Whitehead, 1899; Burbridge, 1938; Kunene, 1965). But storytelling is not the only place where it is useful to have iconic means to evoke sensory scenes.

In Japanese medical interactions, doctors and patients can use ideophones to express sensations that are otherwise hard to verbalise (Sakamoto, Ueda, Doizaki, \& Shimizu, 2014). The iconicity of at least some Japanese pain ideophones has been independently established (Iwasaki, Vinson, \& Vigliocco, 2007). Another setting where ideophones are put to use is in joint work, where people need to hone in on the same kind of percepts and demonstrate their expertise in the process (Nuckolls, 1996). In Ashéninka Perené, an Arawak language spoken in Peru, ideophones are used along with iconic gestures in expert-novice interactions, for instance cooking sessions or the preparation of herbal treatments (Mihas, 2013). Ideophones and iconic gestures are well-suited to these kinds of participatory learning situations because they wear their meaning on their sleeve. Embedded in hands-on learning situations, they function as "scaffolding tools" that "contribute to the formation and distribution of embodied knowledge" (Mihas, 2013, p. 57). In this sense, ideophones are quite like iconic gestures, which have been shown to enhance comprehension by providing alternative, analogical representations that highlight perceptual-motor information (Alibali \& Kita, 2010; Campisi \& Özyürek, 2013). 
If the perceptual analogies provided by ideophones are useful in this kind of explicitly didactic situation, it is not hard to imagine that they may also facilitate aspects of language learning. This has been the focus of a rich vein of experimental work in developmental psychology. At least since Yoshida (2004), it has been hypothesised that ideophones may provide an "iconic bridge between sound and meaning" (Yoshida, 2004, p. 21) that may help in word learning (for a recent review, see Perniss \& Vigliocco, 2014). Experiments with newly created iconic words for manner of motion show that ideophone-like words are easier to learn than arbitrary words for young toddlers as well as for adults (Imai, Kita, Nagumo, \& Okada, 2008; Yoshida, 2012; Miyazaki et al., 2013). A comparison of Japanese adjectives and ideophones found that ideophones are easier to learn for adult participants (Lockwood et al., 2016).

In sum, while early philologists working on the basis of English speculated that imitative words were of little use except as "playthings" (Müller, 1861), empirical work on languages around the world paints a different picture. Far from mere toys, ideophones emerge as important communicative tools. From patients expressing pain sensations to young children learning their first motion words, ideophones show how iconicity can bridge sound and sense.

\subsection{Theoretical consequences}

The prominence of iconicity in ideophones is not without consequences for broader linguistic theory. One implication, argued most forcefully by Diffloth (1972), is that ideophones form an important counterexample to the principle of duality of patterning: the idea that words combine meaningless phonemes to form meaningful morphemes (Hockett, 1960; Blevins, 2012). As Diffloth notes, systematic iconic vowel alternations in ideophones would lead one to analyse vowel height as a morpheme, while similar alternations in consonants would mean the same for consonant voicing, and "once we begin the search for recurrent partials with associated meanings, there seems to be no way to stop" (Diffloth, 1972, p. 442). The problem is similar to the inbetween status of phonaesthemes in morphological theory (Bergen, 2004; Kwon \& Round, 2014), but it is compounded for ideophones because rather than isolated clusters of vocabulary, ideophones can form lexical classes on the same order of magnitude as nouns and verbs.

Zwicky and Pullum's theory of expressive morphology (Zwicky \& Pullum, 1987) attempts to plug this theoretical hole by quarantining ideophones and putting them "in a domain orthogonal to the grammar," along with language play and expletive infixation. Others have argued for giving ideophones their full due. McCarthy used evidence from ideophones in an influential account of nonconcatenative morphology and noted, "these exotic phenomena pervade the world's languages with a regularity and complexity that makes them both essential and ideal for testing any theory of morphology" (McCarthy, 1983, p. 135). The advantages extend to phonology: iconic patterns in Korean and Japanese ideophones played a crucial role in seminal accounts of the nature of phonological features (Kim-Renaud, 1978; Mester \& Itô, 1989). The hybrid nature of ideophones - as words that are (i) vocal gestures partaking in analogical and iconic modes of meaning, quite unlike arbitrary lexical items and yet at the same time (ii) conventionalised forms mostly built using regular phonemes - has made them a crucial testing ground for many areas of theoretical linguistics (Dingemanse, 2018; Ferrara \& Hodge, 2018).

An influential line of work in experimental psychology attaches great weight to a particular type of cross-modal association first identified by Gestalt psychologists like Köhler, in which nonwords like maluma and takete are linked to rounded versus jagged shapes. This form of "sound-symbolism," recently reincarnated in the form of bouba and kiki, has attracted much attention and is often claimed to provide insight into matters of language evolution and language learning (Ramachandran \& Hubbard, 2001). Ideophones provide an exciting possibility to 
compare such lab-induced cross-modal experiences to iconic associations actually attested in natural languages. Recent work shows that naïve experimental subjects are sensitive to iconicity in ideophones (Iwasaki et al., 2007; Revill, Namy, DeFife, \& Nygaard, 2014), but that success rates in guessing their meanings are substantially lower than those obtained in experiments with pseudowords. So ideophones provide a reality check for the power of iconicity in natural language. But they also exhibit many cross-modal associations beyond maluma and takete (Westermann, 1927; Vigliocco \& Kita, 2006): a fertile testing ground for the influence of iconicity on language processing, communication, and learning.

\section{In closing: the relevance of ideophones for linguistics}

Ideophones are increasingly recognised as a major word class found in many of the world's languages. Here we have reviewed three key topics related to the place of ideophones in the language sciences:

Definition. Like other major word classes, ideophones show a number of prototypical properties while also allowing a degree of language-specific variation. Key properties of ideophones include their marked forms, their depictive semiotics, and their sensory meanings. As expected, languages differ in the degree to which these properties describe ideophones, but together they capture a prototypical core close to Doke's original characterisation: "A vivid representation of an idea in sound".

Integration. To declare ideophones as deviant or unintegrated is to miss important generalisations about their relation to other subsystems and levels of linguistic structure. While ideophones do deviate from prosaic words in some respects, they do so in regular ways and with a systematicity of their own. And while many ideophones are characterised by syntactic independence, their varying degrees of syntactic integration sheds light on processes of ideophonisation and deideophonisation, and shows how language combines descriptive and depictive uses of speech material.

Iconicity. While not all ideophones are iconic to the same degree, ideophones remain one of the best places to see lexical iconicity in action. Iconicity in ideophones helps word learning and communication in a wide range of contexts. Iconic mappings between form and meaning show some universal tendencies but also less widespread patterns, making ideophones a natural laboratory for the scientific study of how people link sound and sense.

These topics do not nearly exhaust the richness of recent research on ideophones (for reviews, see Vigliocco \& Kita, 2006; Akita, 2015; Armoskaite \& Koskinen, 2017; Ibarretxe-Antuńano, 2017; Svantesson, 2017). The increasing availability of descriptive, theoretical, and experimental work on ideophones in diverse languages is likely to inspire further work on a much broader range of topics.

\section{Further reading}

Childs, G.T. (1994). African Ideophones. In Hinton et al. (eds) Sound symbolism. Cambridge: Cambridge University Press.

Wide-ranging review paper on ideophone systems of African languages, with several observations of relevance for the global typology of ideophones. One of the earliest papers arguing for a prototype definition of ideophones.

Diffloth, G. (1972). Notes on expressive meaning. Chicago Linguistic Society, 8, 440-447.

Short and rich paper on the implications of ideophones for linguistic theory, using data from Korean and Austroasiatic languages. 
Hamano, S. (1998). The sound-symbolic system of Japanese. Stanford: CSLI Publications.

A comprehensive description of the phonosemantic system of Japanese ideophones.

Hinton, L., Nichols, J., \& Ohala, J. J. (Eds.). (1994). Sound symbolism. Cambridge: Cambridge University Press.

The first collection of papers on ideophones and sound symbolism covering fundamental issues in linguistic, psychological, and biological approaches to sound-symbolic phenomena in different parts of the world.

Iwasaki, N., Sells, P., \& Akita, K. (Eds.). (2017). The grammar of Japanese mimetics: Perspectives from structure, acquisition, and translation. London: Routledge.

The grammatical aspect of Japanese ideophones and their learnability and translatability.

Kita, S. (1997). Two-dimensional semantic analysis of Japanese mimetics. Linguistics, 35(2), 379415.

Influential study of the syntax and semantics of Japanese ideophones, proposing that ideophones partake in an "affecto-imagistic" dimension of semantics distinct from propositional semantics of prosaic words.

Kunene, D. P. (1965). “The Ideophone in Southern Sotho.” Journal of African Languages, 4, 1939.

Groundbreaking paper on ideophones in Sotho, covering phonology, morphosyntax, and gesture. Locus classicus of the idea that ideophones are performances that invite the listener to imagine the sensory scene depicted.

Nuckolls, J. B. (1999). “The Case for Sound Symbolism.” Annual Review of Anthropology, 28, $225-252$.

Influential review of descriptive, typological and historical linguistic work on ideophones (including onomatopoeia), phonaesthemes and other sound-symbolic phenomena.

Samarin, W. J. (1970). "Inventory and Choice in Expressive Language.” Word, 26, 153-169. One of the earliest typological overviews of ideophones, focusing on their expressive functions as aesthetic words.

Vigliocco, G., \& Kita, S. (2006). "Language-Specific Properties of the Lexicon: Implications for Learning and Processing." Language and Cognitive Processes, 21(7-8), 790-816.

Review article singling out the importance of ideophones for studies of language learning and processing in psycholinguistics and psychology.

Voeltz, F. K. E., \& Kilian-Hatz, C. (Eds.). (2001). Ideophones. Amsterdam: John Benjamins. The second monumental collection of papers on ideophones, many of which are descriptions of ideophones in indigenous languages in Africa.

\section{Links to digital materials}

Akita, K. (2005-2010). Bibliographies of sound-symbolic phenomena. https://sites.google.com/site/akitambo/Home/biblio (last accessed 21 March 2019)

National Institute for Japanese Language and Linguistics. (2015-present). NINJAL-LWP for $B C C W J$ (NLB). http://nlb.ninjal.ac.jp/ (last accessed 21 March 2019; this is a search system for a corpus of written Japanese that has an ideophone search function)

Nuckolls, J. B., Swanson, T. D., Sun, D., Rice, A., \& Hatton, S. (2016-present). Quechua Real Words: An Audiovisual ANTI-Dictionary of Expressive Quechua Ideophones. http://quechuarealwords-dev.byu.edu (last accessed 21 March 2019) 


\section{References}

Akita, K. (2009). A Grammar of Sound-Symbolic Words in Japanese: Theoretical Approaches to Iconic and Lexical Properties of Japanese Mimetics (PhD dissertation). Kobe University, Kobe. Retrieved from http://www.lib.kobe-u.ac.jp/handle_gakui/D1004724

Akita, K. (2013a). Constraints on the semantic extension of onomatopoeia. The Public Journal of Semiotics, 5(1), 21-37.

Akita, K. (2013b). The lexical iconicity hierarchy and its grammatical correlates. In L. Elleström, O. Fischer, \& C. Ljungberg (Eds.), Iconic Investigations (pp. 331-350). Amsterdam: John Benjamins Publishing Company.

Akita, K. (2015). Sound symbolism. In J.-O. Östman \& J. Verschueren (Eds.), Handbook of Pragmatics (pp. 1-24). Amsterdam: John Benjamins.

Akita, K., \& Usuki, T. (2016). A constructional account of the 'optional' quotative marking on Japanese mimetics. Journal of Linguistics, 52(2), 245-275. https://doi.org/10.1017/S0022226715000171

Alibali, M. W., \& Kita, S. (2010). Gesture highlights perceptually present information for speakers. Gesture, 10(1), 3-28. https://doi.org/10.1075/gest.10.1.02ali

Ameka, F. K. (2001). Ideophones and the Nature of the Adjective Word Class in Ewe. In F. K. E. Voeltz \& C. Kilian-Hatz (Eds.), Ideophones (pp. 25-48). Amsterdam: John Benjamins.

Armoskaite, S., \& Koskinen, P. (2017). Structuring sensory imagery: ideophones across languages and cultures. Canadian Journal of Linguistics/Revue Canadienne de Linguistique, 1-5. https://doi.org/10.1017/cnj.2017.12

Aston, W. G. (1894). Japanese Onomatopes and the Origin of Language. The Journal of the Anthropological Institute of Great Britain and Ireland, 23, 332-362.

Bartens, A. (2000). Ideophones and Sound Symbolism in Atlantic Creoles. Saarijärvi: Gummerus Printing.

Bergen, B. K. (2004). The psychological reality of phonaesthemes. Language, 80(2), 290-311.

Blevins, J. (2012). Duality of patterning: Absolute universal or statistical tendency? Language and Cognition, 4(4). https://doi.org/10.1515/langcog-2012-0016

Bodomo, A. B. (2006). The structure of ideophones in African and Asian languages: The case of Dagaare and Cantonese. In J. M. Mugane, J. P. Hutchison, \& D. A. Worman (Eds.), Selected Proceedings of the 35th Annual Conference on African Linguistics: African Languages and Linguistics in Broad Perspectives (pp. 203-213). Harvard: Harvard University Press.

Bowler, M., \& Gluckman, J. (2017). Intensifying ideophones in three Luhya languages. In V. Hohaus \& W. Rothe (Eds.), Proceedings of TripleA 4. Göteborg.

Burbridge, A. (1938). The use of the ideophone. Bantu Studies, 12(3), 234.

Campisi, E., \& Özyürek, A. (2013). Iconicity as a communicative strategy: Recipient design in multimodal demonstrations for adults and children. Journal of Pragmatics, 47(1), 14-27. https://doi.org/10.1016/j.pragma.2012.12.007

Childs, G. T. (1988). The phonology and morphology of Kisi (PhD dissertation). University of California, Berkeley. 
Childs, G. T. (1994). African Ideophones. In L. Hinton, J. Nichols, \& J. J. Ohala (Eds.), Sound Symbolism (pp. 178-204). Cambridge: Cambridge University Press.

Childs, G. T. (2001). Research on Ideophones, Whither Hence? The Need for a Social Theory of Ideophones. In F. K. E. Voeltz \& C. Kilian-Hatz (Eds.), Ideophones (pp. 63-73). Amsterdam: John Benjamins.

Childs, G. T. (2014). Constraints on violating constraints: How languages reconcile the twin dicta of "Be different" and "Be recognizably language." Pragmatics and Society, 5(3), 341-354. https://doi.org/10.1075/ps.5.3.02chi

Clark, H. H., \& Gerrig, R. J. (1990). Quotations as Demonstrations. Language, 66(4), 764-805.

Croft, W. (2001). Radical Construction Grammar. Oxford: Oxford University Press.

Dhoorre, C. S., \& Tosco, M. (1998). 111 Somali Ideophones. Journal of African Cultural Studies, 11(2), 125-156.

Diffloth, G. (1972). Notes on expressive meaning. Chicago Linguistic Society, 8, 440-447.

Diffloth, G. (1979). Expressive Phonology and Prosaic Phonology in Mon-Khmer. In T. L. Thongkum (Ed.), Studies in Mon-Khmer and Thai Phonology and Phonetics in Honor of E. Henderson (pp. 49-59). Bangkok: Chulalongkorn University Press.

Dingemanse, M. (2012). Advances in the cross-linguistic study of ideophones. Language and Linguistics Compass, 6(10), 654-672. https://doi.org/10.1002/lnc3.361

Dingemanse, M. (2018). Redrawing the margins of language: Lessons from research on ideophones. Glossa: A Journal of General Linguistics, 3(1), 1-30. https://doi.org/10.5334/gjgl.444

Dingemanse, M., \& Akita, K. (2017). An inverse relation between expressiveness and grammatical integration: on the morphosyntactic typology of ideophones, with special reference to Japanese. Journal of Linguistics, 53(3), 501-532. https://doi.org/10.1017/S002222671600030X

Doke, C. M. (1935). Bantu Linguistic Terminology. London: Longmans, Green, and Co.

Dryer, M. S. (1997). Are grammatical relations universal? In J. Bybee, J. Haiman, \& S. A. Thompson (Eds.), Essays on Language Function and Language Type (pp. 115-143). Amsterdam: John Benjamins.

Enfield, N. J. (2007). A Grammar of Lao. Berlin: Mouton de Gruyter.

Fawcett, A. (2018, January). Ideophone integration and expressiveness in Wao Terero. Presentation presented at the SSILA 2018, Salt Lake City, Utah.

Ferrara, L., \& Hodge, G. (2018). Language as Description, Indication, and Depiction. Frontiers in Psychology, 9. https://doi.org/10.3389/fpsyg.2018.00716

Franco, L. (2017). L-syntax and phono-symbolism: on the status of ideophones in complex. Canadian Journal of Linguistics/Revue Canadienne de Linguistique, 1-37. https://doi.org/10.1017/cnj.2017.7

Gasser, M., Sethuraman, N., \& Hockema, S. (2010). Iconicity in expressives: An empirical investigation. In S. Rice \& J. Newman (Eds.), Experimental and Empirical Methods in the Study of Conceptual Structure, Discourse, and Language (pp. 163-180). Stanford, CA: CSLI 
Publications.

Güldemann, T. (2008). Quotative Indexes in African languages: a synchronic and diachronic survey. Berlin: Mouton de Gruyter.

Hamano, S. S. (1988). The syntax of mimetic words and iconicity. Journal of the Associations of Teachers of Japanese, 22(2), 135-149.

Hamano, S. S. (1998). The Sound-Symbolic System of Japanese. Stanford: CSLI.

Haspelmath, M. (2007). Pre-established categories don't exist: Consequences for language description and typology. Linguistic Typology, 11(1), 119-132. https://doi.org/10.1515/LINGTY.2007.011

Herlofsky, W. J. (1998). The Linguistic Biophilia / Biophobia Hypothesis and the Role of Iconic Expressions in Biologically Prepared Learning, 35(7), 11-19.

Hockett, C. F. (1960). The Origin of Speech. Scientific American, 203(3), 89-96.

Ibarretxe-Antuñano, I. (2006). Sound Symbolism and Motion in Basque. Lincom Europa.

Ibarretxe-Antuñano, I. (2017). Basque ideophones from a typological perspective. The Canadian Journal of Linguistics / La Revue Canadienne de Linguistique, 62(2), 196-220.

Imai, M., Kita, S., Nagumo, M., \& Okada, H. (2008). Sound symbolism facilitates early verb learning. Cognition, 109(1), 54-65. https://doi.org/10.1016/j.cognition.2008.07.015

Itô, J., \& Mester, R. A. (1995). Japanese phonology. In J. A. Goldsmith (Ed.), The Handbook of Phonological Theory (pp. 817-838). Massachusetts, MA: Blackwell.

Iwasaki, N., Vinson, D. P., \& Vigliocco, G. (2007). How does it hurt, kiri-kiri or siku-siku?: Japanese mimetic words of pain perceived by Japanese speakers and English speakers. In M. Minami (Ed.), Applying theory and research to learning Japanese as a foreign language (pp. $2-$ 19). Newcastle: Cambridge Scholars Publishing.

Johnson, M. M. (1976). Toward a definition of the ideophone in Bantu. Working Papers in Linguistics, 21, 240-253.

Kakehi, H., Tamori, I., \& Schourup, L. C. (Eds.). (1996). Dictionary of iconic expressions in Japanese. Berlin; New York: Mouton de Gruyter.

Kellersmann, J. (2017). Hindi-Ideophone. Berlin: Verlag Paul Schmitt.

Kim-Renaud, Y.-K. (1978). Semantic Features in Phonology: Evidence from Vowel Harmony in Korean. Korean Linguistics, 1(1), 1-18. https://doi.org/10.1075/kl.1.01ykk

Kita, S. (1997). Two-dimensional semantic analysis of Japanese mimetics. Linguistics, 35, 379415.

Klamer, M. (2002). Semantically Motivated Lexical Patterns: A Study of Dutch and Kambera Expressives. Language, 78(2), 258-86.

Kruspe, N. (2004). A grammar of Semelai. Cambridge: Cambridge University Press.

Kunene, D. P. (1965). The ideophone in Southern Sotho. Journal of African Languages, 4, 19-39.

Kwon, N. (2018). Iconicity correlated with vowel harmony in Korean ideophones. Laboratory Phonology, 9(1). https://doi.org/10.5334/labphon.53 
Kwon, N., \& Round, E. R. (2014). Phonaesthemes in morphological theory. Morphology, 25(1), 1-27. https://doi.org/10.1007/s11525-014-9250-z

Laing, C. E. (2014). A phonological analysis of onomatopoeia in early word production. First Language, 34(5), 387-405. https://doi.org/10.1177/0142723714550110

Langdon, M. (1994). Noise words in Guaraní. In L. Hinton, J. Nichols, \& J. J. Ohala (Eds.), Sound Symbolism (pp. 107-114). Cambridge: Cambridge University Press.

Lockwood, G., Hagoort, P., \& Dingemanse, M. (2016). How iconicity helps people learn new words: neural correlates and individual differences in sound-symbolic bootstrapping. Collabra, 2(1), 1-15. https://doi.org/10.1525/collabra.42

Mattes, V. (2007). Types of reduplication: a case study of Bikol (PhD thesis). Graz University, Graz.

Mattes, V. (2018). Iconicity in the lexicon: The semantic categories of lexical reduplication. Studies in Language. International Journal Sponsored by the Foundation "Foundations of Language," 41(4), 813-842. https://doi.org/10.1075/sl.16024.mat

McCarthy, J. J. (1983). Phonological features and morphological structure. In J. F. Richardson, M. Marks, \& A. Chuckerman (Eds.), Papers from the Parasession on the Interplay of Phonology, Morphology and Syntax (pp. 135-161). Chicago: Chicago Linguistic Society.

McFarland, T. (2010). Ideophones and Templatic Morphology in Totonac. In J. Wohlgemuth (Ed.), Rara \& Rarissima: Documenting the Fringes of Linguistic Diversity (pp. 235-246). Berlin, Germany: Mouton de Gruyter. xiii.

Mester, R. A., \& Itô, J. (1989). Feature Predictability and Underspecification: Palatal Prosody in Japanese Mimetics. Language, 65(2), 258-293. https://doi.org/10.2307/415333

Mihas, E. (2012). Ideophones in Alto Perene (Arawak) from Eastern Peru. Studies in Language, 36(2), 300-344. https://doi.org/10.1075/sl.36.2.04mih

Mihas, E. (2013). Composite ideophone-gesture utterances in the Ashéninka Perené 'community of practice', an Amazonian Arawak society from Central-Eastern Peru. Gesture, 13(1), 28-62. https://doi.org/10.1075/gest.13.1.02mih

Mithun, M. (1982). The Synchronic and Diachronic Behavior of Plops, Squeaks, Croaks, Sighs, and Moans. International Journal of American Linguistics, 48(1), 49-58.

Miyazaki, M., Hidaka, S., Imai, M., Yeung, H. H., Kantartzis, K., Okada, H., \& Kita, S. (2013). The facilitatory role of sound symbolism in infant word learning. In M. Knauff, M. Pauen, N. Sebanz, \& I. Wachsmuth (Eds.), CogSci 2013: the 35th Annual Conference of the Cognitive Science Society (pp. 3080-3085). Berlin: Cognitive Science Society.

Moore, C. (2015). An ideological history of the English term onomatopoeia. In M. Adams, L. J. Brinton, \& R. D. Fulk (Eds.), Studies in the History of the English Language VI: Evidence and Method in Histories of English (pp. 307-320). Berlin: Walter de Gruyter. https://doi.org/10.1515/9783110345957.307

Müller, M. (1861). Lectures on the Science of Language (Vol. 1). London: Longmans, Green.

Newman, P. (1968). Ideophones from a syntactic point of view. Journal of West African Languages, $5,107-117$.

Newman, P. (2001). Are Ideophones Really as Weird and Extra-Systematic as Linguists Make 
them Out to Be? In F. K. E. Voeltz \& C. Kilian-Hatz (Eds.), Ideophones (pp. 251-258). Amsterdam: John Benjamins.

Nuckolls, J. B. (1996). Sounds Like Life: Sound-Symbolic Grammar, Performance, and Cognition in Pastaza Quechua. New York: Oxford University Press.

Nuckolls, J. B. (1999). The Case for Sound Symbolism. Annual Review of Anthropology, 28, 225252.

Nuckolls, J. B., Nielsen, E., Stanley, J. A., \& Hopper, R. (2016). The Systematic Stretching and Contracting of Ideophonic Phonology in Pastaza Quichua. International Journal of American Linguistics, 82(1), 95-116. https://doi.org/10.1086/684425

Park, J. (2018). Nik-kan ryoo-gengo ni okeru onomatope no gengo-teki toogoosei ni kansuru taisyoo-kenkyuu [A contrastive study of the linguistic integration of ideophones in Japanese and Korean] (PhD dissertation). Nagoya University, Nagoya.

Perniss, P., \& Vigliocco, G. (2014). The bridge of iconicity: from a world of experience to the experience of language. Philosophical Transactions of the Royal Society B: Biological Sciences, 369(1651), 20130300.

Ramachandran, V. S., \& Hubbard, E. M. (2001). Synaesthesia: a window into perception, thought and language. Journal of Consciousness Studies, 8(12), 3-34.

Reiter, S. (2012). Ideophones in Awetí (PhD dissertation). Universität zu Köln, Köln.

Revill, K. P., Namy, L. L., DeFife, L. C., \& Nygaard, L. C. (2014). Cross-linguistic sound symbolism and crossmodal correspondence: Evidence from fMRI and DTI. Brain and Language, 128(1), 18-24. https://doi.org/10.1016/j.bandl.2013.11.002

Sakamoto, M., Ueda, Y., Doizaki, R., \& Shimizu, Y. (2014). Communication Support System Between Japanese Patients and Foreign Doctors Using Onomatopoeia to Express Pain Symptoms. Journal of Advanced Computational Intelligence and Intelligent Informatics, 18(6), 1020-1026.

Samarin, W. J. (1965). Perspective on African ideophones. African Studies, 24(2), 117-121.

Samarin, W. J. (1971). Survey of Bantu ideophones. African Language Studies, 12, 130-168.

Schaefer, R. P., \& Egbokhare, F. O. (2002). On the Status of Do/Say Verbs with Emai Ideophones. Anthropological Linguistics, 44(3), 278-96.

Svantesson, J.-O. (2017). Sound symbolism: the role of word sound in meaning. Wiley Interdisciplinary Reviews: Cognitive Science, e0144, 1-12. https://doi.org/10.1002/wcs.1441

Tamori, I., \& Schourup, L. (1999). Onomatope: Keitai-to imi [Onomatopoeia: Form and meaning]. Tokyo: Kurosio Publishers.

Tedlock, D. (1999). Ideophone. Journal of Linguistic Anthropology, 9(1-2), 118-120.

Tufvesson, S. (2011). Analogy-making in the Semai Sensory World. The Senses and Society, 6(1), 86-95. https://doi.org/10.2752/174589311X12893982233876

Urtel, H. (1919). Zur baskischen Onomatopoesis. Sitzungsberichte Der Akademie Der Wissenschaften Berlin, XIII.

Vidal, O. E. (1852). Introductory Remarks. In S. A. Crowther (Ed.), A Vocabulary of the Yoruba 
language (pp. 1-38). London: Seeleys.

Vigliocco, G., \& Kita, S. (2006). Language-specific properties of the lexicon: Implications for learning and processing. Language and Cognitive Processes, 21(7-8), 790-816.

Watson, R. L. (2001). A Comparison of Some Southeast Asian Ideophones with Some African Ideophones. In F. K. E. Voeltz \& C. Kilian-Hatz (Eds.), Ideophones (pp. 385-405). Amsterdam: John Benjamins.

Westermann, D. H. (1927). Laut, Ton und Sinn in westafrikanischen Sudansprachen. In F. Boas (Ed.), Festschrift Meinhof (pp. 315-328). Hamburg: L. Friederichsen.

Whitehead, J. (1899). Grammar and Dictionary of the Bobangi Language. London: Kegan Paul, Trench, Trübner and Co.

Yoshida, H. (2004). Iconicity in language learning: The role of mimetics in word learning tasks (PhD thesis). Indiana University, Bloomington, IN.

Yoshida, H. (2012). A Cross-Linguistic Study of Sound Symbolism in Children's Verb Learning. Journal of Cognition and Development, 13(2), 232-265. https://doi.org/10.1080/15248372.2011.573515

Zwicky, A. M., \& Pullum, G. K. (1987). Plain Morphology and Expressive Morphology. In J. Aske, Beery, Natasha, L. Michaelis, \& H. Filip (Eds.), Proceedings of the Thirteenth Annual Meeting of the Berkeley Linguistics Society (Vol. VII, pp. 330-340). Berkeley: Berkeley Linguistics Society.

(C) The Authors

Cite as:

Akita, Kimi \& Dingemanse, Mark. 2019. Ideophones (Mimetics, Expressives). In Oxford Research Encyclopedia of Linguistics (ed. Mark Aronoff). Oxford University Press. doi: 10.1093/acrefore/9780199384655.013.477 